Theories \& Applications, the International Edition

Printed Version : (ISSN 2090-5262)

Online Version : (ISSN 2090-5270)

July 2014, Volume 4, No. 2 Pages (23 - 31)

\title{
A Proposed E-Book on Movement Education for Female - Teacher Students in the Faculty of Education.
}

\author{
Ibrahim Abdel-Razik Ahmed Selem
}

Associate Professor, Faculty of Physical Education, Al-Taaf University, Kingdome of Saudi Arabia.

Ahmed Ibrahim Ahmed Azab

Associate Professor, Faculty of Physical Education, Al-Taaf University, Kingdome of Saudi Arabia..

\begin{abstract}
The research aims at designing an electronic book on movement education for female - teacher students in the department of kindergarten in the Faculty of Education, at Taif University in the kingdom of Saudi Arabia

To achieve the goals of the study, both researchers used the descriptive methodology, where a questionnaire was designed and applied to a random sample of (400) kindergarten female teachers.

In the light of the research goals, framework of the scientific methodology used, available data and information for both researchers, as well as the statistical analysis of the research results, the researchers formed the general outline of the book in terms of goals, content, teaching methods, instructional media and evaluation methods. They could also turn it into an electronic form. Both researchers recommend the necessity of subjecting the proposed e-book on movement education for experimentation to know the extent of its appropriateness.
\end{abstract}

Introduction

$\mathrm{E}^{\mathrm{s}}$ ducation is considered a life aspect most influenced by the scientific revolution that prevailed the world during the past years. Traditional educational types and methods are no longer appropriate to keep pace with this age and meet its needs. As a result, interest in direct education has shifted to individual learning that put a greater responsibility on the learner through discovery and experimentation. Teacher's role has changed from being a single source of information to the role of a director, a counselor and an organizer of educational experiences. This change in roles requires the necessity of reviewing traditional curricula and converting them to electronic ones.

Educationalists see that electronic curricula can have many advantages, of which they can transfer the educational process from the teacher to the learner, make it learnercentered, increase its effectiveness and positivity all the time, develop the learner's skills of research, investigation and self-learning, communication and social skills (CastilloMerino \& Serradell-López, 2014), participation and discussion (Zhang \& Cheng, 2012), and cooperation through chat rooms, mail, forums or educational blogs (Malik \& Khurshed , 2011).

A lot of study and research results assured the importance of using electronic education and electronic curricula in achieving a lot of learning outcomes such as student achievement (Abulibdeh \& Hassan, 2011), Engineering (Eugene, \& Clark, 2012), Science and Technology (Priem, De Craemer,\& Calu, 2011), mathematics (kiboss, 2012),
Science (Yalçin, \& Bayrakçeken, 2010), Language (Mutlu, \& Eröz-Tuga, 2013) and Music (Adileh, 2012).

Consequently, electronic education has become inevitable due to the many problems of the educational process at the Arab level consisting in the big number of learners, which is not in proportion with the limited capacity of the educational institutions. It has also become necessary to equip teachers in an electronic environment so that they can manipulate it in the future job market.

Hence, faculties of education, as places specialized in teacher preparation, should shoulder the responsibility of freeing education from conventional curricula, adopting electronic courses that are appropriate for contemporary changes, and providing their graduates with the necessary professional sufficiency for success in their practical life and career.

There are several studies that dealt with preparing electronic courses in physical education. The results assured that using electronic books and courses makes learning easier, faster and more effective. (Ching-Huei \& I-Chia,2012; Huang, Hsin, Chin, Hung \& Yu, 2011; Huang, Liao, Liu, Yang \& Yu,2010; Juniu,2011).

Due to the special nature of girls' education in the Saudi society, the subject of movement education in the department of kindergarten in faculties of education is taught for female students theoretically only and through closed TV circles, since Saudi universities use specialized men only to compensate for faculty shortage in female staff and not tolerate mixing up at the same time, in addition to the insufficient time for the subject teaching. It is taught for 
only one university term for the fourth level of female students as much as two hours per week. Moreover, female student trends towards movement education and physical activity in general are characterized with passivity.

Out of this, both researchers thought of designing an electronic book on movement education for female - teacher students in the department of kindergarten in the Faculty of Education, Taif University, seeking to develop the educational process and manipulating some deficiencies in their preparation program in the subject of movement education. This may lead to facilitating the difficulties of its learning and developing their teaching competency.

Goal of the research:

The research aims at designing a proposed e-book in the course of movement education of the child for kindergarten female students in the Faculty of Education, at Taif University, in the kingdom of Saudi Arabia.

Procedures of the research

\section{Methodology:}

Both researchers used the descriptive method for its appropriateness for the nature of the study.

Sample:
A sample of (400) kindergarten female teachers, educationally qualified and experienced with not less than (3) years, were selected randomly from (5) governorates representing different regions in Saudi Arabia.

\section{Instruments:}

A questionnaire of constructing the content of the proposed e-book on movement education:

Resorting to specialized references and related studies, four primary axes of the questionnaire were determined, then the appropriate statements under each axis were formulated. The questionnaire was submitted in its initial form to a set of specialized experts. Based upon reformulating some phrases and excluding others, the final form of the questionnaire included (123) statements and thus became ready for the calculation of the scientific coefficients.

The scientific coefficients of the questionnaire

Validity:

The questionnaire validity was calculated by proving the validity of the internal consistency when applying the questionnaire to a random sample of (40) staff members getting a doctoral degree with not less than five-year experience in teaching movement education outside the basic research sample. See Tables (1-2).

Table (1)

Correlation coefficient between the statement and axis sum for the questionnaire (under research) $(n=40)$

\begin{tabular}{|c|c|c|c|c|c|c|c|c|c|}
\hline \multicolumn{2}{|c|}{ First axis } & \multicolumn{2}{|c|}{ Second axis } & \multicolumn{2}{|c|}{$\begin{array}{l}\text { Second axis } \\
\text { (continued) }\end{array}$} & \multicolumn{2}{|c|}{$\begin{array}{c}\text { Second axis } \\
\text { (continued) }\end{array}$} & \multicolumn{2}{|c|}{$\begin{array}{l}\text { Second axis } \\
\text { (continued) }\end{array}$} \\
\hline $\begin{array}{c}\mathbf{R} \\
\text { value }\end{array}$ & Statement & $\begin{array}{c}\mathbf{R} \\
\text { value }\end{array}$ & Statement & $R$ value & Statement & $\begin{array}{c}\mathbf{R} \\
\text { value }\end{array}$ & Statement & $R$ value & Statement \\
\hline 1 & 0.371 & 21 & 0.789 & 48 & 0.521 & 75 & 0.336 & 102 & 0.765 \\
\hline 2 & 0.579 & 22 & 0.412 & 49 & 0.47 & 76 & 0.343 & 103 & 0.799 \\
\hline 3 & 0.499 & 23 & 0.671 & 50 & 0.765 & 77 & 0.521 & 104 & 0.794 \\
\hline 4 & 0.455 & 24 & 0.479 & 51 & 0.63 & 78 & 0.61 & 105 & 0.458 \\
\hline 5 & 0.348 & 25 & 0.325 & 52 & 0.336 & 79 & 0.63 & \multicolumn{2}{|c|}{ Third axis } \\
\hline 6 & 0.573 & 26 & 0.65 & 53 & 0.709 & 80 & 0.335 & Statement & $R$ value \\
\hline 7 & 0.338 & 27 & 0.352 & 54 & 0.336 & 81 & 0.745 & 106 & 0.8 \\
\hline 8 & 0.324 & 28 & 0.335 & 55 & 0.65 & 82 & 0.622 & 107 & 0.748 \\
\hline 9 & 0.385 & 29 & 0.714 & 56 & 0.765 & 83 & 0.61 & 108 & 0.695 \\
\hline 10 & 0.359 & 30 & 0.635 & 57 & 0.336 & 84 & 0.765 & 109 & 0.748 \\
\hline 11 & 0.38 & 31 & 0.656 & 58 & 0.491 & 85 & 0.65 & 110 & 0.504 \\
\hline 12 & 0.47 & 32 & 0.342 & 59 & 0.765 & 86 & 0.765 & 111 & 0.397 \\
\hline 13 & 0.458 & 33 & 0.396 & 60 & 0.336 & 87 & 0.346 & 112 & 0.652 \\
\hline 14 & 0.359 & 34 & 0.412 & 61 & 0.65 & 88 & 0.336 & 113 & 0.774 \\
\hline 15 & 0.504 & 35 & 0.647 & 62 & 0.765 & 89 & 0.501 & 114 & 0.388 \\
\hline 16 & 0.332 & 36 & 0.737 & 63 & 0.336 & 90 & 0.336 & 115 & 0.61 \\
\hline 17 & 0.392 & 37 & 0.512 & 64 & 0.685 & 91 & 0.61 & 116 & 0.354 \\
\hline
\end{tabular}




\begin{tabular}{|c|c|c|c|c|c|c|c|c|c|}
\hline \multicolumn{2}{|c|}{ First axis } & \multicolumn{2}{|c|}{ Second axis } & \multicolumn{2}{|c|}{$\begin{array}{l}\text { Second axis } \\
\text { (continued) }\end{array}$} & \multicolumn{2}{|c|}{$\begin{array}{c}\text { Second axis } \\
\text { (continued) }\end{array}$} & \multicolumn{2}{|c|}{$\begin{array}{l}\text { Second axis } \\
\text { (continued) }\end{array}$} \\
\hline $\begin{array}{c}\mathbf{R} \\
\text { value }\end{array}$ & Statement & $\begin{array}{c}\mathbf{R} \\
\text { value }\end{array}$ & Statement & $R$ value & Statement & $\begin{array}{c}\mathbf{R} \\
\text { value }\end{array}$ & Statement & $R$ value & Statement \\
\hline 18 & 0.377 & 38 & 0.352 & 65 & 0.352 & 92 & 0.343 & 117 & 0.525 \\
\hline 19 & 0.485 & 39 & 0.572 & 66 & 0.331 & 93 & 0.638 & 118 & 0.774 \\
\hline \multirow[t]{8}{*}{20} & 0.731 & 40 & 0.655 & 67 & 0.765 & 94 & 0.794 & 119 & 0.564 \\
\hline & & 41 & 0.404 & 68 & 0.375 & 95 & 0.765 & 120 & 0.429 \\
\hline & & 42 & 0.466 & 69 & 0.765 & 96 & 0.765 & \multicolumn{2}{|c|}{ Fourth axis } \\
\hline & & 43 & 0.476 & 70 & 0.603 & 97 & 0.491 & Statement & $R$ value \\
\hline & & 44 & 0.563 & 71 & 0.491 & 98 & 0.765 & 121 & 0.388 \\
\hline & & 45 & 0.556 & 72 & 0.765 & 99 & 0.745 & 122 & 0.824 \\
\hline & & 46 & 0.589 & 73 & 0.352 & 100 & 0.765 & 123 & 0.666 \\
\hline & & 47 & 0.622 & 74 & 0.765 & 101 & 0.392 & & \\
\hline
\end{tabular}

Tabulated $(\mathrm{r})$ value $(\mathbf{0 . 0 5})=(\mathbf{0 . 2 7 3})$

Table 1 above shows that correlation coefficients in the first axis ranged between $(0.324,0.731)$, in the second axis

$(0.325,0.799)$, in the third axis $(0.354,0.800)$, in the fourth axis $(0.388,0.824)$ and they are all statistically significant indicating the validity of these axes.

Table (2)

Correlation coefficient between axes and total sum of the questionnaire (under research) $(n=40)$

\begin{tabular}{|c|c|c|}
\hline Serial & Variable & Correlation coefficient \\
\hline 1 & First axis & 0.832 \\
\hline 2 & Second axis & 0.985 \\
\hline 3 & Third axis & 0.801 \\
\hline 4 & Fourth axis & 0.381 \\
\hline
\end{tabular}

Tabulated $(\mathrm{r})$ value $(\mathbf{0 . 0 5})=(\mathbf{0 . 2 7 3})$

Table 2 above shows that the correlation coefficients ranged between $(0.381,0.985)$. They are statistically significant indicating that the questionnaire axes are at a high degree of validity.

\section{Reliability:}

It is calculated by half split and Alpha Cronbach coefficient. See Table 3

Table (3)

Questionnaire reliability coefficient (under research) $(n=40)$

\begin{tabular}{|c|c|c|c|c|c|c|c|}
\hline \multirow{2}{*}{ serial } & \multirow{2}{*}{ Variable } & \multicolumn{2}{|c|}{ Individual statements } & \multicolumn{2}{|c|}{ Paired statements } & \multirow{2}{*}{ Alpha coefficient } \\
\cline { 3 - 7 } & & Mean & $\begin{array}{c}\text { Standard } \\
\text { deviation }\end{array}$ & Mean & $\begin{array}{c}\text { Standard } \\
\text { deviation }\end{array}$ & & \\
\hline 1 & First axis & $\mathbf{0 . 7 5 6}$ & $\mathbf{0 . 4 3 7}$ & 1.655 & 18.675 & 1.694 & 18.525 \\
\hline 2 & Second axis & $\mathbf{0 . 9 7 5}$ & $\mathbf{0 . 9 5 4}$ & $\mathbf{5 . 6 6 6}$ & $\mathbf{8 0 . 7 2 5}$ & $\mathbf{6 . 1 8 9}$ & $\mathbf{8 2 . 5 5}$ \\
\hline 3 & Third axis & $\mathbf{0 . 8 7 3}$ & $\mathbf{0 . 6 8 4}$ & $\mathbf{1 . 1 7 6}$ & 13.475 & 1.285 & 15.3 \\
\hline 4 & Fourth axis & $\mathbf{0 . 3 0 8}$ & $\mathbf{0 . 3 2 9}$ & $\mathbf{0 . 4 2 3}$ & 1.775 & $\mathbf{0 . 4 0 5}$ & 3.8 \\
\hline
\end{tabular}

Tabulated $(\mathrm{r})$ value $(\mathbf{0 . 0 5})=(\mathbf{0 . 2 7 3})$

Table 3 above shows that reliability coefficients ranged between $(0.308,0.957)$. They are statistically significant correlation coefficients that the questionnaire is at a high degree of reliability.
The final application of the questionnaire:

The questionnaire was applied to a random sample of (400) kindergarten female teachers, starting from Saturday, $6 / 4 / 2013$ up to Sunday, 12/5/2013. See Table 4. 
Table (4)

Opinions of the study sample from kindergarten female teachers about the proposed e-book. $(n=400)$

\begin{tabular}{|c|c|c|c|c|}
\hline \multirow{2}{*}{ Serial } & \multirow{2}{*}{ Axes and Statements } & \multicolumn{2}{|c|}{ Opinion } & \multirow{2}{*}{ Chi Square } \\
\hline & & yes & No & \\
\hline \multicolumn{5}{|c|}{$\begin{array}{l}\text { First axis : goals of the book } \\
\text { First : cognitive goals }\end{array}$} \\
\hline 1 & $\begin{array}{c}\text { Knowing information and cognition of movement education in concept, } \\
\text { philosophy and bases }\end{array}$ & 277 & 123 & $59.29 *$ \\
\hline 2 & Knowing the importance of movement education in kindergarten stage. & 227 & 173 & $7.29 *$ \\
\hline 3 & Knowing movement aspects and dimensions & 276 & 124 & 57.76* \\
\hline 4 & Knowing concepts and terms used in movement education & 265 & 135 & $42.25 *$ \\
\hline 5 & $\begin{array}{c}\text { Knowing organized and administered procedures for movement } \\
\text { education lessons }\end{array}$ & 244 & 156 & 19.36* \\
\hline 6 & Knowing the method of performing basic movement skills. & 269 & 131 & 47.61* \\
\hline 7 & Knowing steps of teaching basic movement skills. & 233 & 167 & 10.89* \\
\hline 8 & $\begin{array}{l}\text { Knowing errors related to performing basic movement skills and } \\
\text { correcting them }\end{array}$ & 225 & 175 & $6.25 *$ \\
\hline 9 & Knowing methods of teaching basic motor skills. & 233 & 167 & 10.89* \\
\hline 10 & Knowing methods of evaluating movement education. & 227 & 173 & $7.29 *$ \\
\hline \multicolumn{5}{|c|}{$\begin{array}{l}\text { Second : Affectional goals } \\
\end{array}$} \\
\hline 11 & Acquiring the desired social attitudes & 258 & 142 & 33.64* \\
\hline 12 & Deepening ethical values & 276 & 124 & 57.76* \\
\hline 13 & Developing voluntary psychological traits & 239 & 161 & $15.21 *$ \\
\hline \multicolumn{5}{|c|}{ Third : Motor goals } \\
\hline 14 & $\begin{array}{c}\text { The ability of applying information and cognition and operating them } \\
\text { in situations of movement performance. }\end{array}$ & 237 & 163 & 13.69* \\
\hline 15 & $\begin{array}{c}\text { The ability of performing basic movement skills at an appropriate level } \\
\text {. }\end{array}$ & 277 & 123 & $59.29 *$ \\
\hline 16 & Acquiring skills of teaching movement education methods & 247 & 153 & 22.09* \\
\hline 17 & $\begin{array}{c}\text { Acquiring skills of organizing and directing children during movement } \\
\text { learning }\end{array}$ & 225 & 175 & $6.25 *$ \\
\hline 18 & Acquiring skills of educating basic movement skills of children & 265 & 135 & 42.25* \\
\hline 19 & $\begin{array}{c}\text { Acquiring skills of organizing and implementing movement education } \\
\text { lessons }\end{array}$ & 236 & 164 & $12.96 *$ \\
\hline 20 & Acquiring skills of evaluating movement performance of the child. & 271 & 129 & 50.41* \\
\hline \multicolumn{5}{|c|}{$\begin{array}{c}\text { Second axis : Content of the book } \\
\text { First : Cognitive aspect } \\
\end{array}$} \\
\hline 21 & Concept and philosophy of movement education & 246 & 154 & 21.16* \\
\hline 22 & Bases of movement education and its goals & 239 & 161 & 15.21* \\
\hline 23 & Motor - perception abilities & 244 & 156 & $19.36 *$ \\
\hline 24 & Basic movement skills & 248 & 152 & 23.04* \\
\hline 25 & Locomotion & 237 & 163 & 13.69* \\
\hline 26 & Stability and balance & 229 & 171 & $8.41 *$ \\
\hline 27 & Control and manipulation & 289 & 111 & 79.21* \\
\hline 28 & Strategies of education and learning in movement education & 276 & 124 & 57.76* \\
\hline \multicolumn{5}{|c|}{$\begin{array}{l}\text { Second : Content of skills and movement activities } \\
\text { A) Locomotion : }\end{array}$} \\
\hline 29 & Walking & 258 & 142 & 33.64* \\
\hline 30 & Running & 271 & 129 & $50.41 *$ \\
\hline 31 & hopping & 114 & 286 & 73.96* \\
\hline 32 & Horizontal jumping & 265 & 135 & 42.25* \\
\hline 33 & Vertical jumping & 229 & 171 & $8.41 *$ \\
\hline
\end{tabular}




\begin{tabular}{|c|c|c|c|c|}
\hline \multirow{2}{*}{ Serial } & \multirow{2}{*}{ Axes and Statements } & \multicolumn{2}{|c|}{ Opinion } & \multirow{2}{*}{ Chi Square } \\
\hline & & yes & No & \\
\hline \multicolumn{5}{|c|}{ B) Stability movements : } \\
\hline 34 & Static balance & 256 & 144 & 31.36* \\
\hline 35 & Dynamic balance & 276 & 124 & 57.76* \\
\hline \multicolumn{5}{|c|}{ C) Control and manipulation } \\
\hline 36 & Catching a rolling ball & 267 & 133 & 44.89* \\
\hline 37 & Holding a large ball with both hands & 289 & 111 & 79.21* \\
\hline 38 & Bouncing and holding with both hands & 271 & 129 & $50.41 *$ \\
\hline 39 & Bouncing a large ball with one hand & 289 & 111 & 79.21* \\
\hline 40 & Overhand throw & 237 & 163 & $13.69 *$ \\
\hline 41 & Underhand throw & 265 & 135 & $42.25 *$ \\
\hline 42 & Single - handed striking & 129 & 271 & 50.41* \\
\hline 43 & Two handed striking & 133 & 267 & 44.89* \\
\hline \multicolumn{5}{|c|}{ D ) Applications of teaching movement education } \\
\hline 44 & Organizing children in movement education & 277 & 123 & $59.29 *$ \\
\hline 45 & A lesson of movement education & 255 & 145 & $30.25 *$ \\
\hline 46 & Evaluating movement performance of the child & 250 & 150 & 25.00* \\
\hline \multicolumn{5}{|c|}{$\begin{array}{c}\text { Third : Selecting and organizing the content of the book : } \\
\text { The content of the proposed e-book is characterized by the following : } \\
\text { First : logical organization }\end{array}$} \\
\hline 47 & Graduality from easy to difficult and from simple to complex & 266 & 134 & 43.56* \\
\hline 48 & Connecting and sequencing of the scientific material & 271 & 129 & $50.41 *$ \\
\hline 49 & Building previous activities on the next activities. & 265 & 135 & 42.25* \\
\hline \multicolumn{5}{|c|}{ B) Psychological organization } \\
\hline 50 & Needs of female students & 249 & 151 & 24.01* \\
\hline 51 & Dispositions and desires of female students & 236 & 164 & 12.96* \\
\hline 52 & Female students' attitudes & 289 & 111 & 79.21* \\
\hline 53 & Individual differences between female teachers & 223 & 177 & $5.29 *$ \\
\hline \multicolumn{5}{|c|}{ G ) Other considerations } \\
\hline 54 & Considering the philosophy of Saudi society & 270 & 130 & 49.00* \\
\hline 55 & Balance between depth and exclusiveness & 230 & 170 & $9.00 *$ \\
\hline 56 & Validity and significance of the content & 279 & 121 & $62.41 *$ \\
\hline 57 & Competency and related goals & 271 & 129 & 50.41* \\
\hline 58 & Relation with the requirements of pre-school child development & 261 & 139 & $37.21 *$ \\
\hline 59 & Flexibility & 234 & 166 & 11.56* \\
\hline 60 & Variation & 265 & 135 & 42.25* \\
\hline 61 & Integration & 281 & 119 & 65.61* \\
\hline 62 & Safety & 273 & 127 & 53.29* \\
\hline 63 & Clarity of concepts & 271 & 129 & 50.41* \\
\hline 64 & Challenging female students' abilities & 249 & 151 & 24.01* \\
\hline \multicolumn{5}{|c|}{$\begin{array}{c}\text { Fourth : Goals of educational units } \\
\text { A) Cognitive goals : } \\
\end{array}$} \\
\hline 65 & Knowing the concept of education and its importance & 244 & 156 & 19.36* \\
\hline 66 & Knowing the concept of physical education and its importance & 265 & 135 & $42.25 *$ \\
\hline 67 & Knowing the concept, bases and goals of movement education & 263 & 137 & $39.69 *$ \\
\hline 68 & $\begin{array}{l}\text { Perceiving the relationship between the education, physical education } \\
\text { and movement education. }\end{array}$ & 287 & 113 & $75.69 *$ \\
\hline
\end{tabular}




\begin{tabular}{|c|c|c|c|c|}
\hline \multirow{2}{*}{ Serial } & \multirow{2}{*}{ Axes and Statements } & \multicolumn{2}{|c|}{ Opinion } & \multirow{2}{*}{ Chi Square } \\
\hline & & yes & No & \\
\hline 69 & $\begin{array}{l}\text { Knowing factors that govern movement performance such as leisure , } \\
\text { effort and flowness. }\end{array}$ & 271 & 129 & 50.41* \\
\hline 70 & Knowing the method of performing locomotion & 289 & 111 & 79.21* \\
\hline 71 & Knowing the steps of educating locomotion & 267 & 133 & 44.89* \\
\hline 72 & $\begin{array}{l}\text { Knowing errors of performing locomotion and methods of their } \\
\text { correction }\end{array}$ & 248 & 152 & 23.04* \\
\hline 73 & Knowing the method of evaluating locomotion performance & 270 & 130 & 49.00* \\
\hline 74 & Knowing the method of performing stability and balance movements. & 271 & 129 & 50.41* \\
\hline 75 & Knowing the steps of educating stability and balance movements. & 244 & 156 & 19.36* \\
\hline 76 & $\begin{array}{l}\text { Knowing errors of performing stability and balance movements and the } \\
\text { methods of their correction. }\end{array}$ & 233 & 167 & $10.89 *$ \\
\hline 77 & $\begin{array}{l}\begin{array}{l}\text { Knowing the method of evaluating the performance of stability and } \\
\text { balance movements. }\end{array} \\
\end{array}$ & 249 & 151 & 24.01* \\
\hline 78 & $\begin{array}{c}\text { Knowing the method of performing control and manipulation } \\
\text { movements. }\end{array}$ & 278 & 122 & $60.84 *$ \\
\hline 79 & Knowing steps of educating control and manipulation movements. & 242 & 158 & 17.64* \\
\hline 80 & $\begin{array}{l}\text { Knowing errors of performing control and manipulation movements } \\
\text { and the methods of its correction. }\end{array}$ & 289 & 111 & 79.21* \\
\hline 81 & $\begin{array}{c}\text { Knowing the method of evaluating control and manipulation } \\
\text { movements' performance. }\end{array}$ & 277 & 123 & $59.29 *$ \\
\hline 82 & Knowing the concepts and terms used in movement education & 265 & 135 & 42.25* \\
\hline 83 & Knowing the methods of teaching movement education. & 263 & 137 & 39.69* \\
\hline 84 & Knowing methods of organizing children in movement education. & 265 & 135 & 42.25* \\
\hline 85 & Knowing components of movement education lessons. & 259 & 141 & 34.81* \\
\hline \multicolumn{5}{|c|}{ b) Affectionate goals : } \\
\hline 86 & Forming positive attitudes towards motor activity. & 289 & 111 & 79.21* \\
\hline 87 & Appreciating the importance of motor activity of the child. & 255 & 145 & 30.25* \\
\hline 88 & Appreciating aesthetic aspect of movement performance. & 256 & 144 & 31.36* \\
\hline 89 & Forming positive attitudes towards teaching movement education & 249 & 151 & 24.01* \\
\hline 90 & Feeling satisfaction after practicing movement activity. & 233 & 167 & 10.89* \\
\hline 91 & $\begin{array}{l}\begin{array}{l}\text { Perceiving the importance of movement activity in developing moral } \\
\text { traits . }\end{array} \\
\end{array}$ & 265 & 135 & 42.25* \\
\hline 92 & Participating positively in the movement activity & 242 & 158 & $17.64 *$ \\
\hline 93 & Acquiring the desired psychological traits . & 276 & 124 & 57.76* \\
\hline \multicolumn{5}{|c|}{ G ) movement goals : } \\
\hline 94 & Performing locomotion correctly. & 249 & 151 & 24.01* \\
\hline 95 & Performing stability and balance movements correctly. & 271 & 129 & 50.41* \\
\hline 96 & Performing control and manipulation movements correctly & 273 & 127 & 53.29* \\
\hline 97 & Educating locomotion for children. & 261 & 139 & $37.21 *$ \\
\hline 98 & Educating stability and balance movements for children & 229 & 171 & $8.41 *$ \\
\hline 99 & Educating control and manipulation movements for children & 278 & 122 & 60.84* \\
\hline 100 & The ability of evaluating locomotion performance & 265 & 135 & 42.25* \\
\hline 101 & The ability of evaluating stability and balance movements & 248 & 152 & 23.04* \\
\hline 102 & The ability of evaluating control and manipulation movements & 267 & 133 & 44.89* \\
\hline 103 & Acquiring methods of teaching movement education & 248 & 152 & 23.04* \\
\hline 104 & Acquiring skills of organizing children during motor learning & 264 & 136 & 40.96* \\
\hline 105 & Acquiring skills of implementing a lesson of the movement education. & 277 & 123 & 59.29* \\
\hline \multicolumn{5}{|c|}{ Third axis : Methods of teaching and instructional media } \\
\hline 106 & Method of learning with articulated presentation & 265 & 135 & 42.25* \\
\hline
\end{tabular}




\begin{tabular}{|c|c|c|c|c|}
\hline \multirow{2}{*}{ Serial } & \multirow{2}{*}{ Axes and Statements } & \multicolumn{2}{|c|}{ Opinion } & \multirow{2}{*}{ Chi Square } \\
\hline & & yes & No & \\
\hline 107 & Method of self-learning & 262 & 138 & 38.44* \\
\hline 108 & Method of application with peers guidance. & 247 & 153 & 22.09* \\
\hline 109 & Method of problems solving & 271 & 129 & 50.41* \\
\hline \multicolumn{5}{|c|}{ Second : Instructional media } \\
\hline 110 & Hyper texts & 289 & 111 & $79.21 *$ \\
\hline 111 & Static pictures & 235 & 165 & $12.25 *$ \\
\hline 112 & Motor sequence pictures & 267 & 133 & $44.89 *$ \\
\hline 113 & Video & 260 & 140 & $36.00 *$ \\
\hline 114 & Animation cartoons & 271 & 129 & $50.41 *$ \\
\hline 115 & Sound & 238 & 162 & $14.44 *$ \\
\hline 116 & E-mail & 245 & 155 & $20.25 *$ \\
\hline 117 & Rasleny "contact me" model & 253 & 147 & $28.09 *$ \\
\hline 118 & Electronic links. & 229 & 171 & $8.41 *$ \\
\hline 119 & Direct communication. & 289 & 111 & 79.21* \\
\hline 120 & Music and sound effects & 153 & 247 & 22.09* \\
\hline \multicolumn{5}{|c|}{$\begin{array}{l}\text { Fourth axis : Methods of evaluation } \\
\text { The following evaluation methods are used in the e-book : }\end{array}$} \\
\hline 121 & Participation and interaction & 265 & 135 & $42.25 *$ \\
\hline 122 & Performing tasks of learning and their activities. & 247 & 153 & 22.09* \\
\hline 123 & The final test & 271 & 129 & $50.41 *$ \\
\hline
\end{tabular}

Tabulated (chi square 2) value at $(0.05)=(3.84)$

Table 4 above shows that the significance direction for all the form statements was on behalf of (yes) except for the statement no. $(31,42,43,120)$, the significance direction was on behalf of ( no ). Based upon this, these statements were removed and the form was renumbered from ( 1: 119) so as to serve as a general framework of the proposed ebook on the movement education .

\section{Preparing the book in its electronic form:}

1. Developing the general goals of the book .

2. Developing the general content of the book and organizing it in four basic units. Each unit includes a set of sub-topics

3. Determining the appropriate design language , where the HTML language was used to construct the static book pages, by using the Microsoft FrontPage program in addition to Java Script to add the effectiveness element to the book .

4. Connecting the book with internet services that increases interaction of female students with its subjects such as common chatting websites, search engines and electronic links .

5. Writing texts and listing files of static and sequential pictures, video and animation cartoons

6. Submitting the electronic book to a set of specialized experts to conduct the required modifications and applying it to a sample of ( 40 ) female students in the department of kindergarten after their study of movement education course . It was shown the appropriateness and attractiveness of the scientific content, the language easiness for female students and easy navigation through the book content .

7. The electronic book was located on the following site : www.drazab.com/me

Discussing the results :

Results of table ( 4 ) indicate the agreement of the study sample from the female teachers on the suggested axes and statements of the electronic book content on movement education at a rate of (119) statements for the fourth axes from total (123) statements after excluding (4) statements . The significance of chi square ${ }^{2}$ according to their responses is as follows :

\section{The first axis : goals of the book}

The study sample from kindergarten female teachers agreed to the appropriateness of all the suggested goals of the electronic book with its three types : ( cognitive affectional - Motor)

The book includes all various goals of comprehensive and integrated development for the female teacher students in mental, affectional and motor ways. The cognitive goals aim at (remembering, understanding, applying, analyzing , 
synthesizing and evaluating) for the female teacher students of information, cognitions and the necessary concepts of different educational aspects related to movement education . The movement goals aim at applying and functioning these cognitions and information in movement learning situations through (observation, imitation, experimentation, practice, adaptation and creativity) to develop teaching skills for the female teacher students so that they can deal with the educational situations in movement education. The affectional goals aim at developing personal aspects accompanying the process of movement education through (attention, reception, response, giving value, organization , characterizing with a value) and that the female student can adjust her behavior and develop her values system .

\section{Second axis : Book content :}

The study sample from kindergarten female teachers agreed to the appropriateness of all the suggested contents of the electronic book in the movement education except for the skills of ( hopping, single - handed striking, striking with two hands ). This may be due to their inappropriateness for kindergarten children.

The researchers attribute the appropriateness of the proposed e-book content to the choice of the content in the light of specialized scientific references on movement education (Joanne \& Keith, 1999; Joanne \& Keith, 2000) in addition to organizing the content in accordance with education philosophy in the Saudi society.

The researchers divided the content into ( 4 ) educational units. The first one is entitled " movement education - the concept, philosophy and strategies of teaching " . The second unit is entitled locomotion movements ". The third unit entitled is " stability and balance movements ". The fourth unit is entitled " control and manipulation movements ". In terms of selecting and organizing the content, the research sample agreed on the appropriateness of all the suggested topics as well as all goals of the suggested electronic book. Both researchers consider that each unit includes :

- The unit number and title.

- $\quad$ The goals of (cognitive, affection and movement ) units.

- The content of the unit : it is a set of sub - topics.

- References: through which new information related to the topics of the units is added.

- Activities of education and learning :

They might be a question which the female student answers, an assignment or special instructions directing her towards using other sources and materials of learning such as accessing a site, loading some files from the Internet, reading a chapter from a book or going to the college library to collect some information related to the unit topic. The female student's answers /activities are sent by the service " contact me" liked to the site.
- Direct chatting website: where there is a special link in each unit by which the female student can communicate with the subject professor or with her colleagues for discussion or interpretation of the unit topics.

Third axis : Methods of teaching and instructional media :

The study sample from the female teachers agreed to the appropriateness of all teaching methods ( the method of learning with articulated presentation, the individual learning , application with peers guidance and problemsolving .

In connection with the instructional media, the study sample agreed to the appropriateness of the following instructional media ( hyper texts , static pictures, motor sequence pictures, animation cartoons, sound, e. mail, the pattern of " contact me " electronic links, direct chatting website), Music and sound effects were excluded. Thin is may due to religious reasons for female teachers.

In this regard (Tsai \& Lee, 2012; Fenouillet and Kaplan, 2011) assured that the successful learning environment should provide a lot of teaching methods and instructional material which enable the learner to learn on their own and flexibly with other learning groups through some tools such as chat rooms, discussion forums and different websites.

Fourth axis: Methods of evaluation :

The study sample from the female teachers agreed to the appropriateness of the suggested evaluation methods represented in :

- Participation and interaction inside the course through effectiveness in using

e-mails, direct chatting websites, the service of " contact me ". $(20 \%)$ of the total score is allocated to this method.

- Educational tasks and activities are allocated ( $40 \%$ ) of the total score

- The final exam of the course content is allocated ( $40 \%$ ) of the total score.

Conclusions and recommendations:

\section{Conclusions}

The proposed e-book on movement education is appropriate for the female teacher students in kindergarten department from the viewpoints of kindergarten female teachers.

\section{Recommendations}

Based upon the study results, both researchers recommend the following :

1. Submitting the proposed e-book on movement education for experimentation to know the reasons for its appropriateness . 
2. Generalizing the experiment to all subjects in the program of preparing kindergarten female teachers.

References

1. Abulibdeh, E.S., \& Hassan, S. S.(2011). Elearning interactions, information technology self-efficacy and student achievement at the University of Sharjah, UAE. Australasian Journal of Educational Technology, 27 (6), 10141025.

2. Adileh, M.(2012). Teaching Music as a University Elective Course through e-Learning. Australian Journal of Music Education,1,71-79.

3. Castillo-Merino, D.,\& Serradell-López, E.(2014). An analysis of the determinants of students' performance in e-learning. Academic Journal Computers in Human Behavior, 30, 476-484.

4. Ching-Huei, C.,\& I-Chia, W.(2012).The interplay between cognitive and motivational variables in a supportive online learning system for secondary physical education. Journal Computers \& Education, 58 (1),542-550.

5. Eugene, W.,\& Clark, K.(2012). E-Learning, Engineering, and Learners of African Descent: A Needs Analysis. Journal of STEM Education: Innovations and Research,13(2),45-57.

6. Fenouillet, F.,\& Kaplan, J.(2011). Impact of Learning Modalities on Academic Success, Jonathan. European Journal of Open, Distance and E-Learning, 20(2),111-136.

7. Huang, C., Chin, S., Hsin, L., Hung, J.,\& Yu, Y. (2011). A Web-based E-learning Platform for Physical Education. Journal of Networks, suppl. Special Issue: Nomadic Services and Applications ,6(5), 721-727.

8. Huang, C., Liao, Y., Liu, C., Yang, C.,\& Yu, Y.(2010). E-learning on Physical education of Utilizing Multimedia Contents.International Conference on Computer Science Education Innovation \& Technology (CSEIT). Proceedings, I25-I28.

9. Joanne, M. L., \& Keith, R. B. (1999).Fundamental motor skills\& movement activities for young children, complete motor skills activities program. The Center for Applied Research in Education, West Nyack, New York.
10. Joanne, M. L., \& Keith, R. B. (2000). Ready to Use Motor skills movement station lesson plans for young children: teaching, remediation and assessment. the Center for Applied Research in Education, West Nyack, New York.

11. Juniu, S.(2011). Pedagogical Uses of Technology in Physical Education. Journal of Physical Education, Recreation \& Dance, 82(9), 41-49.

12. Kiboss, J. K. (2012). Effects of Special ELearning Program on Hearing-Impaired Learners' Achievement and Perceptions of Basic Geometry in Lower Primary Mathematics. journal of Educational Computing Research,46(1), 31-59.

13. Malik, S. K.,\& Khurshed, F. (2011).Nature of Teacher-Students' Interaction in Electronic Learning and Traditional Courses of Higher Education. A Review, Turkish Online Journal of Distance Education,12(4),157-166.

14. Mutlu, A.,\& Eröz-Tuga, B.(2013). The Role of Computer-Assisted Language Learning (CALL) in Promoting Learner Autonomy. Eurasian Journal of Educational Research (EJER), 51, 107-122.

15. Priem, F., De Craemer, R.,\& Calu,T.(2011). ELearning in Science and Technology via a Common Learning Platform in a Lifelong Learning Project, Johan. European Journal of Open, Distance and E-Learning, 12(1),75-97.

16. Tsai,C.,\& Lee,H.(2012). Developing an Appropriate Design for E-Learning with WebMediated Teaching Methods to Enhance LowAchieving Students' Computing Skills: Five Studies in E-Learning Implementation. International Journal of Distance Education Technologies,10(1), 1-30.

17. Yalçin, F. A.,\& Bayrakçeken, S.(2010). The Effect of 5E Learning Model on Pre-Service Science Teachers' Achievement of Acids-Bases Subject, International Online Journal of Educational Sciences, 2 (2), 508-531.

18. Zhang, W.,\& Cheng, Y. (2012). Quality Assurance in E-Learning: PDPP Evaluation Model and Its Application. International Review of Research in Open and Distance Learning, 13(3), 66-82. 